\title{
Accumulation of CD1a-positive Langerhans cells and mast cells in actinic cheilitis
}

\author{
Caliandra Pinto Araújo • Clarissa Araújo Silva Gurgel • \\ Eduardo Antônio Gonçalves Ramos • Valéria Souza Freitas • \\ Aryon de Almeida Barbosa Júnior • Luciana Maria Pedreira Ramalho • \\ Jean Nunes dos Santos
}

Received: 28 July 2010/Accepted: 7 September 2010/Published online: 2 October 2010

(C) Springer Science+Business Media B.V. 2010

\begin{abstract}
LCs and MCs are known to be directly influenced by UV radiation. This study investigated the presence of Langerhans cells (LCs) and mast cells (MCs) in actinic cheilitis (AC) exhibiting epithelial dysplasia (ED). Using immunohistochemistry for CD1a and mast cell tryptase, LCs and MCs density was assessed in 35 cases of AC with different degrees of ED. LCs were found in 32 cases of AC whereas MCs were found in all cases. There was an increase in LCs density irrespective of degree of ED when the cases were compared to normal lip mucosa
\end{abstract}

C. P. Araújo

Department of Oral Pathology, Laboratory of Oral Surgical Pathology, School of Dentistry, Federal University of Bahia, Salvador, Bahia, Brazil

C. A. S. Gurgel - E. A. G. Ramos - A. de Almeida Barbosa Júnior

Gonçalo Moniz Research Center, Oswaldo Cruz Foundation, Salvador, Bahia, Brazil

\section{S. Freitas}

Department of Health, State University of Feira de Santana, Feira de Santana, Bahia, Brazil

L. M. P. Ramalho

Department of Stomatology, School of Dentistry, Federal

University of Bahia, Salvador, Bahia, Brazil

\section{J. N. dos Santos}

Department of Oral Pathology, Laboratory of Oral Surgical Pathology, School of Dentistry, Federal University of Bahia, Salvador, Bahia, Brazil

\section{J. N. dos Santos $(\bowtie)$}

Faculdade de Odontologia, Universidade Federal da Bahia, Avenida Araújo Pinho, 62, Canela, Salvador,

Bahia 40110-150, Brazil

e-mail: jeanunes@ufba.br
$(P=0.04343)$. No statistical difference in LCs density was observed regarding the different degrees of dysplasia $(P>0.05)$. Significant difference in MCs density between mild and moderate dysplasia and normal lip mucosa was found $(P<0.05)$. No significant correlation between LCs and MCs was seen $(P=0.1258)$. Although no correlation could be established between LCs and MCs and the different degrees of ED; it is possible that the accumulation of LCs plays an immunostimulatory and protective role in the defense against progression of dysplasia. Further studies are necessary to determine the role of MCs in the development of AC.

Keywords Actinic chelitis - Langerhans cells · Mast cells · Epithelial dysplasia

\section{Introduction}

Actinic cheilitis (AC) is a premalignant lesion that manifests as a diffuse lesion of the lower lip vermilion resulting from excessive exposure to sunlight. The condition is more frequent in light-skinned individuals. AC is analogous to solar keratosis, exhibiting variable degrees of $\mathrm{ED}$, and may even undergo malignant transformation to squamous cell carcinoma (Cataldo and Doku 1981; Cavalcante et al. 2008; Markopoulos et al. 2004; Rojas et al. 2004; Santos et al. 2003). Histopathologically, AC is characterized by atrophy or acanthosis of the stratified squamous epithelium. The latter can be hyperkeratinized or parakeratinized (Cavalcante et al. 2008; Kaugars et al. 1999; Markopoulos et al. 2004; Santos 2000; Santos et al. 2003). In general, a mild to moderate inflammatory infiltrate mainly consisting of lymphocytes and occasional plasma cells is present in the lamina propria (Cataldo and Doku, 1981; Kaugars et al. 
1999; Santos 2000; Santos et al. 2003), amidst amorphous basophilic degeneration of collagen fibers in superficial connective tissue (Cavalcante et al. 2008; Kaugars et al. 1999; Markopoulos et al. 2004; Rojas et al. 2004; Santos 2000; Santos et al. 2003).

Ultraviolet (UV) radiation, especially UVB (280-315 nm), exerts diverse effects on the immune system of human skin (Facy et al. 2005; Kolgen et al. 2002; Meunier et al. 1995; Norval et al. 2008) and also contributes to the development of AC and lip cancer (Cavalcante et al. 2008; Picascia and Robinson 1987). These effects include the suppression of cellular immunity, such as the disappearance of antigenpresenting cells of the epidermis, called LC (Facy et al. 2005; Kolgen et al. 2002; Meunier et al. 1995). These cells are the main antigen-presenting cells of the epidermis and actively participate in Th1 and Th2 responses, presenting antigens to B or T lymphocytes (Cutler and Jotwani 2004; Holiková et al. 2001).

MCs are bone marrow-derived cells (Chen et al. 2005; Rodewald et al. 1996) widely found in human tissues (Fukushima et al. 2006). Depending on their location and stage of maturation, these cells express different quantities of surface antigens that are involved in cell activation and recognition (Valent et al. 2001). MCs are classified according to the secretion of proteins, called endopeptidases, and they are divided into tryptases and chymases (Caughey 2007). The secretion of these enzymes promotes inflammation, matrix destruction, tissue remodeling, and angiogenesis (Caughey 2007; Huttunen and Harvina 2005). According to Rojas et al. 2005, actinic damage on the epithelial cells activates MCs, and this contributes to the degeneration of connective tissue observed in AC and also stimulate angiogenesis and inflammation; therefore, these cells are important for skin remodeling after actinic damage and mediate the immunosuppression induced by UV rays (Grimbaldeston et al. 2006).

We previously demonstrated an altered pattern of keratin differentiation in AC (Santos et al. 2003). In addition, it is known that cell proliferation associated with an altered differentiation program may cause the development of tumor cells (Hahn and Weinberg 2002). Furthermore, the inflammatory microenvironment modulates cell migration and invasion, facilitating the proliferation of altered cells and contributing to the formation and progression of cancer (Le Bitoux and Stamenkovic 2008; Lin and Karin 2007).

Therefore, as cellular components such as LCs and MCs are known to be directly influenced by UV radiation, the aim of the present study was to investigate by immunohistochemistry the presence of LCs and MCs in AC lesions with different degrees of ED since these lesions, frequently found in the lower lip, show a potential to become malignant.

\section{Materials and methods}

The study was approved by the Ethics Committee of School of Denstistry of the Federal University of Bahia. Thirty-five cases of AC diagnosed at the Laboratory of Surgical Pathology, School of Dentistry, Federal University of Bahia, were studied. Clinical data obtained from the request forms of the anatomopathological exams indicated that $21(60 \%)$ patients were males and $14(40 \%)$ were females, with a mean age of 54.8 years (range 20-75).

For morphological analysis, $4-\mu \mathrm{m}$ thick sections were obtained from material fixed in formalin and embedded in paraffin. The slides obtained for each case were stained with hematoxylin and eosin and analyzed by light microscopy.

Each case ( $n=35$ ) was reassessed based on the histological criteria for the diagnosis and histological grading of ED defined by the World Health Organization for precursor epithelial lesions: mild dysplasia, moderate dysplasia, and severe dysplasia (Gale et al. 2005).

For immunohistochemical analysis, 3- $\mu \mathrm{m}$ thick sections were cut from each tissue specimen. Immunostaining was performed with the streptavidin-biotin complex (LSAB, Dako Cytomation, Glostrup, Denmark) using anti-CD1a antibody (clone MTB1, Novocastra, Newcastle, United Kingdom; dilution 1:30) for the detection of LCs and antimast cell tryptase (clone AA1, Dako Cytomation; dilution 1:50, Glostrup, Denmark) for the detection of MCs. The sections were deparaffinized, rehydrated and washed in distilled water. Next, antigen retrieval was performed with Tris/EDTA buffer, $\mathrm{pH} 9.0$, heated to $96^{\circ} \mathrm{C}$ for $30 \mathrm{~min}$ for $\mathrm{CD} 1 \mathrm{a}$, and by enzymatic digestion with $1 \%$ trypsin at $37^{\circ} \mathrm{C}$ for $20 \mathrm{~min}$, for mast cells. Endogenous peroxidase was blocked by incubation in $3 \%$ hydrogen peroxide for $10 \mathrm{~min}$. The slides were then incubated with the primary antibody for $60 \mathrm{~min}$ in a humid chamber, at room temperature (RT). Then, the slides were washed with $1 \%$ PBS/BSA and incubated with the biotinylated secondary antibodies (link reagent, Dako Cytomation, Glostrup, Denmark) for $60 \mathrm{~min}$, at RT, followed by washing and incubation with the streptavidin-biotin-peroxidase complex. Diaminobenzidine (Dako Cytomation, Glostrup, Denmark) was used as chromogen and the slides were counterstained with Harris hematoxylin for $15 \mathrm{~s}$. As positive control, a fragment of LCs histiocytosis was used for the anti-CD1a antibody and a fragment of pyogenic granuloma presenting marked granulation tissue for MCs. The negative control consisted of replacement of the primary antibody with an antibody of the same isotype as the primary antibody. Three fragments of normal lip mucosa without solar elastosis were also studied for the purpose of comparison.

LCs and MCs were analyzed by a previously trained observer by light microscopy, taking into accounting the 
same areas as those used for histological grading of ED. For the analysis of LCs, the density of CD1a-positive cells was obtained by the observation of immunostained epithelial strata. CD1a-positive cells were counted in up to 10 microscopic fields at final magnification of $200 \times$. For evaluation of the distribution of MCs, all cells present in the superficial and deep lamina propria, including the area of basophilic degeneration, were counted in up to 20 fields at final magnification of $100 \times$. The shape of the cells and the presence of degranulated mast cells were also described.

The descriptive results were expressed as the mean \pm standard deviation (SD) of positive cells per field. Differences between groups (LCs, MCs, degree of ED) were evaluated using the Kruskal-Wallis test, followed by Dunn's test. The correlation between CD1a- and tryptasepositive cells was analyzed using Spearman's correlation coefficient. All statistical calculations were performed using the GraphPad Prism 4.0 program. The level of significance was set at $5 \%$.

\section{Results}

According to the histological parameters defined by the WHO for the diagnosis of epithelial dysplasia, 17 (48.7\%) of the 35 cases were classified as mild dysplasia, 13 $(37.14 \%)$ as moderate dysplasia, and $5(14.29 \%)$ as severe dysplasia.

CD1a-positive LCs were observed in 32 (91.43\%) cases irrespective of presence of inflammation. Most stained cells presented a dendritic aspect and long and irregular cytoplasmic prolongations and were detected in the basal to intermediate layers. No positive cells were found in the stratum corneum in any case. Interstitial dendritic cells were also observed in the superficial lamina propria (Fig. 1). The mean density of positive cells ranged from 0 to 40.1 , and the variations in number of CD1a-positive LCs are presented in Table 1. In addition, an increase in LC density irrespective of the degree of ED was observed when the cases were compared to normal lip mucosa $(P=0.04343$, Kruskal-Wallis test). However, Dunn's post-test revealed no significant difference in LC density when the different degrees of ED were compared separately $(P>0.05)$.

MCs were found throughout the superficial and deep lamina propria, including especially the area corresponding to basophilic degeneration; in this area degranulated mast cells were found. The cells presented a round, angular or elongated shape, and were observed in all cases studied irrespective of presence of inflammation (Fig. 2). Submucosa was not observed in all cases, but when present mast cells were also detected around medium-caliber blood vessels in the presence or absence of basophilic degeneration. The mean density of MCs ranged from 7.0 to 65.5 , and the variations in number of MCs are presented in Table 1.

Comparison of mast cell density between the different degrees of ED and normal mucosa showed a higher density of these cells in cases of mild and moderate dysplasia $(P<0.05$, Kruskal-Wallis test and Dunn's post-test $)$ (Fig. 3). Spearman's correlation coefficient revealed no significant correlation between the $\mathrm{CD} 1 \mathrm{a}$ and mast cell tryptase markers in the sample studied $(P=0.1258$, rs $=0.2637$ ).

\section{Discussion}

LCs play a role in the initiation and regulation of immune responses, especially in the stimulation of lymphocyte proliferation (Hubert et al. 2005; Schroder et al. 2006). These cells detect antigens on the epidermis, migrate to lymph nodes that drain the region and present these antigens to $\mathrm{T}$ lymphocytes, thus acting as sentinels of actinic damage to the skin (Cutler and Jotwani 2004; Kaugars et al. 1999; Schroder et al. 2006; Timares et al. 2008). The mobilization and migration of LCs are induced and regulated by cytokines, mainly tumor necrosis factor alpha $(\mathrm{TNF}-\alpha)$ and interleukin-1 $\beta$ (IL-1 $\beta$ ) (Antonopoulos et al. 2008; Facy et al. 2005; Cumberbatch et al. 2002). It is important to state that Kolgen et al. 2002 report that this migratory capacity of LCs is impaired after actinic damage, with consequent accumulation of these cells in the dermis.

Chronic exposure to sunlight has been indicated as the main etiological agent of both $\mathrm{AC}$ and squamous cell carcinoma of lip (Cavalcante et al. 2008; Cataldo and Doku 1981; Markopoulos et al. 2004; Santos et al. 2003). UV radiation exerts various biological effects on the human skin, including the suppression of immune reactions and a reduction in the number of LCs (Facy et al. 2005; Kolgen et al. 2002; Meunier et al. 1995). This reduction in the number of epidermal LCs and functional disturbances after UVB radiation can be explained by two still controversial mechanisms: migration of structurally and functionally altered LCs to the lymph nodes (Kolgen et al. 2002) or induction of apoptosis of these cells (Takashima 2005; Rattis et al. 1998). Kolgen et al. 2002 raised blisters on the skin of healthy individuals overexposed to UVB and showed a considerable number of Langerhans cells in the blister fluid, concluding that these cells came from the epidermis and thus the reduction of Langerhans cells is attributed not only to apoptosis, but the migration of cells to the lymph nodes. Experiments on mice showed that LCs apoptosis is induced by UVB radiation through the production of reactive oxygen species by keratinocytes, among 

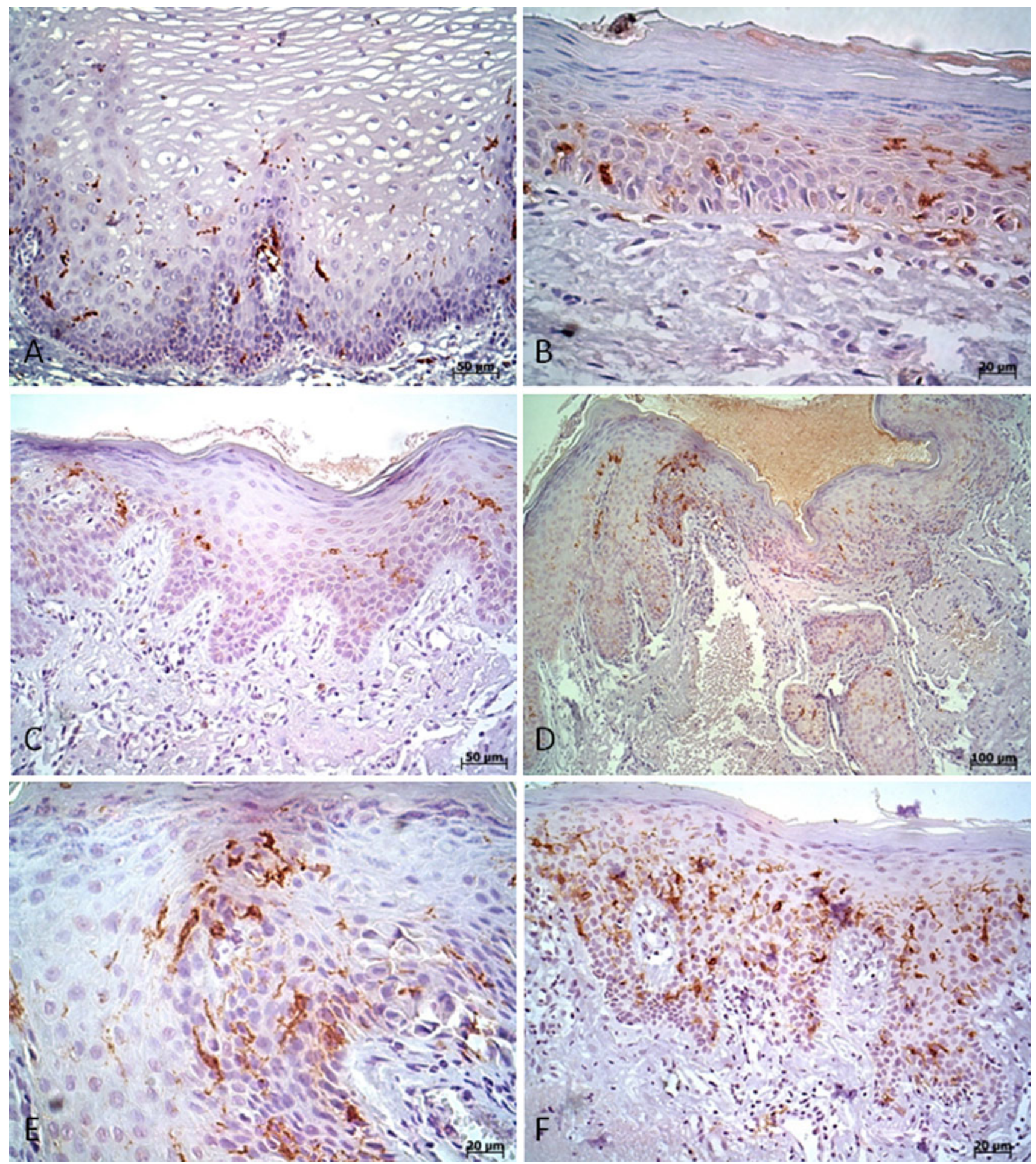

Fig. 1 Langerhans cells in normal oral mucosa and actinic cheilitis with different degrees of dysplasia. a Normal oral mucosa exhibiting CD1a-positive Langerhans cells reaching stratum basal and upper layers. b Actinic cheilitis with mild dysplasia exhibiting CD1apositive Langerhans cells reaching basal and intermediate layers; note dendritic cells in the subepithelial region. c Actinic cheilitis with mild dysplasia displaying CD1a-positive Langerhans cells located mainly

in the basal and parabasal layers. d Actinic cheilitis with moderate dysplasia displaying CD1a-positive Langerhans cells located along the epithelium lining. e Detail of previous figure displaying marked distribution of CD1a-positive Langerhans cells; note the dendritic extensions presented by the cells. f Actinic cheilitis with severe dysplasia showing marked distribution of dendritic cells; note that these cells are not found in the stratum corneum 
Table 1 Variations in number of CD1a-positive LCs and MCs in AC lesions with different degrees of ED and normal mucosa

\begin{tabular}{|c|c|c|c|c|}
\hline & $\begin{array}{l}\text { Mild Dysplasia } \\
\text { Mean (SD) }\end{array}$ & $\begin{array}{l}\text { Moderate Dysplasia } \\
\text { Mean (SD) }\end{array}$ & $\begin{array}{l}\text { Severe Dysplasia } \\
\text { Mean (SD) }\end{array}$ & $\begin{array}{l}\text { Normal Lip Mucosa } \\
\text { Mean (SD) }\end{array}$ \\
\hline Cd1a positive cells & $53.00(48.65)$ & $32.91(29.54)$ & $85.25(82.70)$ & $29.33(13.01)$ \\
\hline Mast cell tryptase positive cells & $213.20(108.4)$ & $202.60(80.39)$ & $136.00(71.07)$ & $36.00(10.48)$ \\
\hline
\end{tabular}

$S D$ standard deviation

other mechanisms (Takashima 2005). Schwartz et al. 1998 also demonstrated a possible induction of dendritic cell apoptosis through the stimulation of suppressor $\mathrm{T}$ cells via the FAS pathway. Probably, other immunological aspects especially those related to the host should be further investigated.

Despite reports of the influence of UV radiation on the behavior of LCs and on the development of AC lesions, to our knowledge, there are no studies in the English literature investigating the relationship between these cells and AC lesions. In the present study, CD1a-positive Langerhans cells was observed in almost $92 \%$ of AC lesions, and although this research could not demonstrate the direct involvement of UV on the disappearance of these cells in $\mathrm{AC}$ as observed in basal cell carcinomas (De Melo et al. 2006), it shows the importance of dendritic cells as effector cells of the oral mucosal immune response (Cutler and Jotwani 2006; Mowat 2005).

With respect to the degree of ED shown by AC lesions, in the present study the number of LCs did not differ significantly between the different degrees of ED, although an increase in cell counts was observed when compared to control. The present results permit to attribute the increase in the density of LCs in AC lesions to an immunostimulatory and protective signal of the lip or organism, after the lesion has become chronic, possibly from adjacent healthy tissue. It is possible that an elevated number of these cells may indicate a possible limit between AC and the development of squamous cell carcinoma of the lip. However, further studies are necessary to clarify this aspect. Furthermore, some patients may have developed AC many years ago and protected their lips from direct exposure to sunlight during recent years whereas others may presently have been exposed to excessive UV radiation on a daily basis, and this might explain the variation in cell count.

Some authors have shown a high density of LCs in oral squamous cell carcinoma, but this increase was attributed to the presence of an inflammatory infiltrate in the tumor Albuquerque et al. (2003). In the present study, the increase in the density of LCs in AC lesions was found in the presence or absence of inflammatory cells. The presence of a large number of LCs in different types of tumors predicts a better prognosis, a fact demonstrating the efficiency of these cells in the tumor immune response. Despite these aspects, La Rocca et al. 2000 observed that the higher the infiltration of CD1a positive dendritic cells in primary invasive ductal breast carcinoma, the lower the possibility of lymph nodes metastases, suggesting that CD1a positive cells might be a favorable prognostic marker in these tumors. Miyagi et al. 2001 also associated the presence of a large number of these cells in HPV-infected lung cancer with a better prognosis. Taken together, these data thus support the capacity of these cells in monitoring cancerigenic lesions.

We studied the distribution of MCs in AC lesions because of the role of these cells in the immunosuppression provoked by UV radiation (Grimbaldeston et al. 2006), matrix degradation, induction of angiogenesis, and degeneration of connective tissue in solar elastosis (Caughey 2007; Huttunen and Harvina 2005; Rojas et al. 2005). An increase in the number of these cells was observed in cases of discrete and moderate dysplasias when compared to control (Erbagci and Erkiliç 2002; Hart et al. 2000; Hart et al. 2001). In this study, MCs were found to be concentrated in the region of the lamina propria, whereas Rojas et al. 2004 observed a higher accumulation of these cells at the epithelial/connective tissue junction and in connective tissue itself. According to many authors, the number of MCs is significantly increased in skin exposed to radiation as well as in different types of cancer (Bosset et al. 2003; Gomes et al. 2008; Grimbaldeston et al. 2006; Hart et al. 2000; Hart et al. 2001; Humphreys et al. 2000; Iamaroon et al. 2003; Rojas et al. 2005).

Although no significant association between MCs and the degree of epithelial dysplasia was observed in the present study, the number of these cells was increased when compared to normal lip mucosa (Costa et al. 2009; Gomes et al. 2008). The presence of MCs and their distribution in premalignant and malignant lesions indicate an association of these cells with the severity of these lesions, as well as an increase in the immunosuppression provoked by UV radiation. In this respect, some investigators showed a larger mean number of MCs (40.1) in lip cancer when compared to different degrees of ED (moderate: 30.5, severe: 28.6) in AC and normal oral mucosa (Gomes et al. 2008). Costa et al. 2009 studying 37 cases of squamous cell carcinoma of the lip and 15 cases of AC, observed a similar number of MCs in the two lesions; however, the number of 

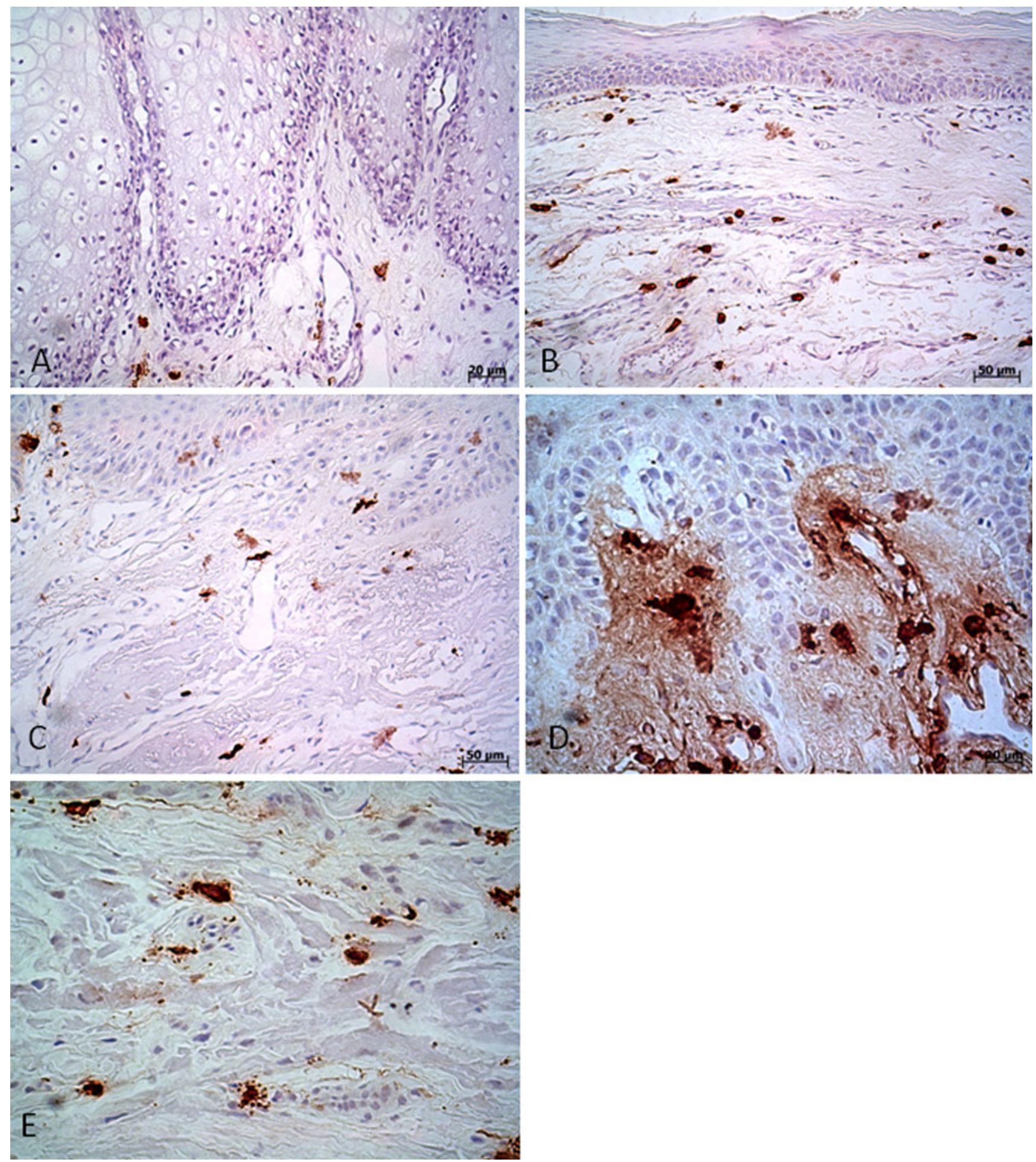

Fig. 2 Mast cells in normal oral mucosa and actinic cheilitis with different degrees of dysplasia. a Normal oral mucosa showing few mast cells in the superficial lamina propria and close to vessels. b Actinic cheilitis with mild dysplasia showing several mast cells located mainly around the areas corresponding to the solar elastosis.

these cells was significantly higher when compared to normal lip mucosa. Michailidou et al. 2008 also found an elevated number of MCs when comparing normal oral

c Actinic cheilitis with moderate dysplasia displaying mast cells with elongated shape. d Actinic cheilitis with severe dysplasia showing several angular mast cells close to vessels. e Actinic cheilitis with severe dysplasia showing degranulated mast cells around the area corresponding to the solar elastosis; these cells are close to vessels

mucosa and cases of leukoplakia with discrete, moderate and severe dysplasia and squamous cell carcinoma. Despite their role in tumor development and progression, MCs are 


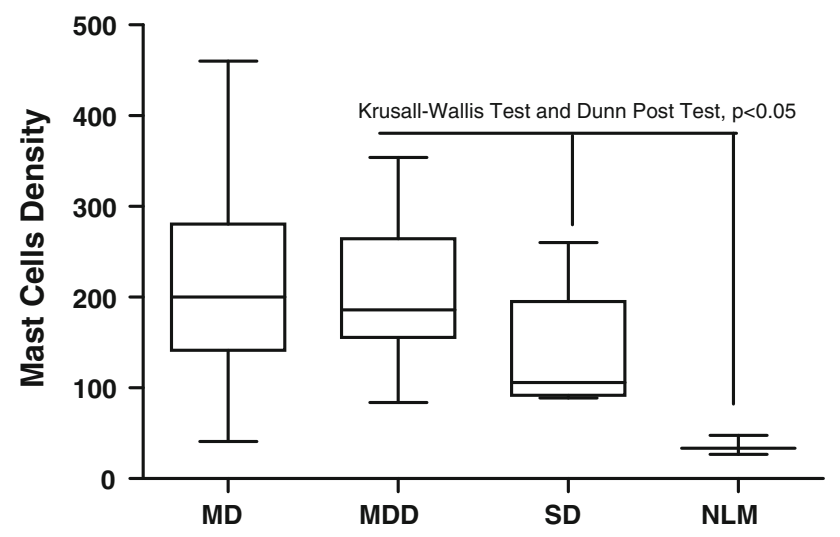

Fig. 3 Distribution of MCs in AC with different degrees of ED and normal mucosa $(M D$ mild dysplasia, $M D D$ moderate dysplasia, $S D$ severe dysplasia, $N L M$ normal lip mucosa)

directly affected by UV radiation which alters their potential to release mediators (Guhl et al. 2005; Hart et al. 1998). Furthermore, MCs are important for the structural maintenance of skin through the production of growth factors and fibroblasts (Erbagci and Erkiliç 2002; Maurer et al. 2003). It is important to state that the participation of mast cells in epithelial remodeling and tissue repair after actinic damage has also been reported (Grimbaldeston et al. 2006; Humphreys et al. 2000; Huttunen and Harvina 2005; Nagata et al. 2003; Wang et al. 2005).

One of the function of mast cells includes their involvement in the release of mediators such as histamine, IL- 8 and TNF- $\alpha$ and in the accumulation of neutrophils at sites of inflammation (Clydesdale et al. 2001; Endoh et al. 2007; Henz 2008; Grimbaldeston et al. 2006; Guhl et al. 2005). In the present study, these cells were seen in areas of inflammation. However, they were also observed in the absence of inflammation and located close to tortuous blood vessels of the AC lesions, irrespective of their shape. According to Costa et al. 2009, angiogenesis is significantly increased in lip carcinoma when compared to AC. Some investigators suggest that in different cancers resulting from exposure to UV radiation or not, the increase in the number of MCs is associated with inflammation and angiogenesis, favoring the occurrence of cancer and its proliferation (Fisher et al. 1989; Grimbaldeston et al. 2002; Kankkunen et al. 1997; Ribatti et al. 2007; Rojas et al. 2005). In contrast, an association between the presence of MCs and a more favorable prognosis has been reported by others (Aaltomaa et al. 1993; Chan et al. 2005; Fleischmann et al. 2009; Grimbaldeston et al. 2006; Welsh et al. 2005), either increasing survival as observed in patients with lung and ovarian carcinomas (Chan et al. 2005; Welsh et al. 2005) or inducing tumor fibrosis and thus limiting the growth and metastasis of malignant cells (Ruoss et al. 1991). Taken together, the role of MCs in tumor progression does not seem to be well defined. Nevertheless, it is likely that accumulation of MCs influences the development of AC. In addition, as AC becomes malignant, MCs may induce an immunosuppressive state, reducing the host response against tumor antigens and thus permitting the occurrence of squamous cell carcinoma (Grimbaldeston et al. 2006). Further studies are necessary to better understand the role of mast cells in lesions caused by UV radiation.

In conclusion, although no correlation could be established between the density of LCs and mast cells in AC lesions and the different degrees of ED, the present study suggests that the accumulation of CD1a-positive LCs is an important immunostimulatory and protector agent in the defense against progression of ED. Further studies are necessary to determine the role of MCs in the development of AC.

Acknowledgments This study was supported by CNPq (Edital Universal, processo 485964/2006-6).

\section{References}

Aaltomaa S, Lipponen P, Papinaho S et al (1993) Mast cells in breast cancer. Anticancer Res 13:785-788

Albuquerque RL Jr, Miguel MC, Costa AL et al (2003) Correlation of c-erbB-2 and S-100 expression with the malignancy grading and anatomical site in oral squamous cell carcinoma. Int J Exp Pathol $84: 259-265$

Antonopoulos C, Cumberbatch M, Mee JB et al (2008) IL-18 is a key proximal mediator of contact hypersensitivity and allergeninduced Langerhans cell migration in murine epidermis. J Leukocyte Biol 83:1-7

Bosset S, Bonnet-Duquennoy M, Barre P et al (2003) Photoageing shows histological features of chronic skin inflammation without clinical and molecular abnormalities. Br J Dermatol 149:826-835

Cataldo E, Doku HC (1981) Solar cheilitis. J Dermatol Surg Oncol 7:985-989

Caughey GH (2007) Mast cell tryptases and chymases in inflammation and host defense. Immunol Rev 217:141-154

Cavalcante ASR, Anbinder AL, Carvalho YR (2008) Actinic Cheilitis: clinical and histological features. J Oral Maxillofac Surg 66:498-503

Chan Jk, Magistris A, Loizzi V et al (2005) Mast cell density, angiogenesis, blood clotting, and prognosis in women with advanced ovarian cancer. Ginecol Oncol 99:20-25

Chen CC, Grimbaldeston MA, Tsai M (2005) Identification of mast cell progenitors in adult mice. Proc Natl Acad Acad Sci USA 102:11408-11413

Clydesdale GJ, Dandie GW, Muller HK (2001) Ultraviolet light induce injury: Immunological and inflammatory effects. Immunol Cell Biol 79:547-568

Costa NL, Oton-Leite AF, Cheim-Júnior AP et al (2009) Density and migration of mast cells in lip squamous cell carcinoma and actinic cheilitis. Histol Histopathol 24:457-465

Cumberbatch M, Dearman RJ, Groves RW (2002) Differential regulation of epidermal Langerhans cell migration by interleukins (IL)-1alpha and IL-1beta during irritant- and allergeninduced cutaneous immune responses. Toxicol Appl Pharmacol 182:126-135 
Cutler CW, Jotwani R (2004) Antigen-presentation and the role of dendritic cells in periodontitis. Periodontol 35:135-157

Cutler CW, Jotwani R (2006) Dendritic cells at the oral mucosal interface. J Dent Res 85:678-689

De Melo MR Jr, Araújo-Filho JL, Patu VJ (2006) Langerhans cells in cutaneous tumours: immunohistochemistry study using a computer image analysis system. J Mol Hist 37:321-325

Endoh I, DI Girolamo N, Hampartzoumian T (2007) Ultraviolet B irradiation selectively increases the production of interleukin-8 in human cord blood-derived mast cells. Exp Immunol 148: $161-167$

Erbagci Z, Erkiliç S (2002) Can smoking and/or occupational UV exposure have any role in the development of the morpheaform basal cell carcinoma? A critical role for peritumoral mast cells. Int J Dermatol 41:275-278

Facy V, Flouret V, Régnier M et al (2005) Reactivity of Langerhans cells in human reconstructed epidermis to known allergens and UV radiation. Toxicol Vitro 19:787-795

Fisher ER, Paik RM, Rockette H et al (1989) Prognostic significance of eosinophils and mast cell in rectal cancer. Human Pathol 20:159-163

Fleischmann A, Schlomm T, Kollermann J et al (2009) Immunological microenvironment in prostate cancer: high mast cell densities are associated with favorable tumor characteristics and good prognosis. Prostate 69:976-981

Fukushima H, Ohsawa M, Ikura I et al (2006) Mast cell in difuse large B-cell lymphoma; their role in fibrosis. Histopathology 49: 498-505

Gale N, Pich BZ, Sidransky D et al (2005) Epithelial precursor lesions. In: Barnes L, Eveson JW, Reichart P, Sidransky D (eds) World Heatlth Organisation classification of tumours-pathology \& genetics-head and neck tumours. IARC press scientific publications, Lyon, pp 177-179

Gomes AP, Johann JE, Lovatto GG et al (2008) Comparative analysis of the mast cell density in normal oral mucosa, actinic cheilitis and lip squamous cell carcinoma. Braz Dent J 19:186-189

Grimbaldeston MA, Skov L, Finlay-Jones JJ et al (2002) Increased dermal mast cell prevallence and susceptibility to development of basal carcinoma in humans. Methods 28:90-96

Grimbaldeston MA, Finlay-Jones JJ, Hart PH (2006) Mast cells in photodamaged skin: what is their role in skin cancer? Photochem Photobiol Sci 5:177-183

Guhl S, Stefaniak R, Strathmann M et al (2005) Bivalent effect of UV light on human skin mast cells-low-level mediator release at baseline but potent suppression upon mast cell triggering. J Invest Dermatol 124:453-456

Hahn WC, Weinberg RA (2002) Rules for making human tumor cells. N Engl J Med 347:1593-1603

Hart PH, Grimbaldeston MA, Swift GJ et al (1998) TNF modulates susceptibility to UVB-induced systemic immunomodulation in mice by effects on dermal mast cell prevalence. Eur J Immunol 28:2893-2901

Hart PH, Grimbaldeston MA, Finlay-Jones JJ (2000) Mast cells in UV-B-induced immunosuppression. J Photochem Photobiol Biol 55:81-87

Hart PH, Grimbaldeston MA, Finlay-Jones JJ (2001) Sunlight, immunosuppression and skin cancer: role of histamine and mast cells. Clin Exp Pharmacol Physiol 28:1-8

Henz B (2008) Exploring the mast cell enigma: a personal reflection of what remains to be done. Exp Dermatol 17:91-99

Holiková Z, Hercogavá J, Pizák J et al (2001) Dendritic cells in the skin and mucosa: what's new. J Eur Acad Dermatol Venerol 15:116-120

Hubert P, Bousarghin L, Greimers R et al (2005) Production of large numbers of Langerhans cells with intraephithelial migration ability in vitro. Exp Dermatol 14:469-477
Humphreys TR, Monteiro MR, Murphy GF (2000) Mast cells and dendritic cells in basal cell carcinoma stroma. Dermatol Surg 26:200-204

Huttunen M, Harvina IT (2005) Mast cell tryptase and chymase in chronic leg ulcers: chymase is potentially destructive to epithelium and is controlled by proteinase inhibitors. Br J Dermatol 152:1149-1160

Iamaroon A, Pongsiriwet S, Jittidecharaks S et al (2003) Increase of mast cells and tumor angiogenesis in oral squamous cell carcinoma. J Oral Pathol Med 35:195-199

Kankkunen JP, Harvina IT, Naukkarinen A (1997) Quantitative analysis of triptase and chymase containing mast cells in begin and malignant breast lesions. Int J Cancer 72:385-388

Kaugars GE, Pillion T, Svirsky JA et al (1999) Actinic cheilitis: a review of 152 cases. Oral Surg Oral Med Oral Pathol Oral Radiol Endod 88:181-186

Kolgen W, Both H, Van Weelden H et al (2002) Epidermal Langerhans cell depletion after artificial ultraviolet B irradiation of human skin In vivo: apoptosis versus migration. J Invest Dermatol 118:812-817

La Rocca G, Anzalone R, Corrao S et al (2000) Cd1a down-regulation in primary invasive ductal breast carcinoma may predict regional lymph node invasion and patient outcome. Histopathology 52:203-212

Le Bitoux MA, Stamenkovic I (2008) Tumor-host interactions: the role of inflammation. Histochem Cell Biol 130:1079-1090

Lin WW, Karin M (2007) A cytokine-mediated link between innate immunity, inflammation, and cancer. J Clin Invest 117:1175-1183

Markopoulos A, Albanidou-Farmaki E, Kayavis I (2004) Actinic cheilitis: clinical and pathologic characteristics in 65 cases. Oral Dis 10:212-216

Maurer M, Theoharides T, Granstein RD et al (2003) What is the physiological function of mast cell? Exp Dermatol 12:886-910

Meunier L, Bata-Csorgo Z, Cooper KD (1995) In human dermis, ultraviolety radiation induces expansion of a CD36 + CD11b + CD1-macrophage subset by infiltration and proliferation; $\mathrm{CD} 1$ + Langerhans-like dendritic antigen presenting cells are concomitantly depleted. J Invest Dermatol 105:782-788

Michailidou EZ, Markopoulos AK, Antoniades DZ (2008) Mast cell and angiogenesis in oral malignant and premalignant lesions. Open Dent J 28:126-132

Miyagi J, Kinjo T, Tsuhako K et al (2001) Extremely high Langerhans cell infiltration contributes to the favourable prognosis of HPV-infected squamous cell carcinoma and adenocarcinoma of the lung. Histopathology 38:355-367

Mowat AM (2005) Dendritic cells and immune responses to orally administered antigens. Vaccine 23:1797-1799

Nagata M, Shijubo N, Walls AF (2003) Chymase-positive mast cells in small sized adenocarcinoma of the lung. Virchows Arch 443: $565-573$

Norval M, Mcloone P, Lesiak A (2008) The effect of chronic ultraviolet radiation on the human immune system. Photochem Photobiol 84:19-28

Picascia DD, Robinson JK (1987) Actinic cheilitis: a review of the etiology, differential diagnosis and treatment. J Am Acad Dermatol 17:255-264

Rattis FM, Concha M, Dalbiez-Gauthier C et al (1998) Effects of ultraviolet $\mathrm{B}$ radiation on human Langerhans cells. Functional alteration of CD86 upregulation and induction of apoptotic cell death. J Invest Dermatol 111:373-379

Ribatti D, Finato N, Crivellato E et al (2007) Angiogenesis and mast cells in human breast cancer sentinel lymph nodes with and without micrometastases. Histopathology 51:837-842

Rodewald HR, Dessing M, Dvorak AM (1996) Identification of a committed precursor for the mast cell lineage. Science 271: $818-822$ 
Rojas IG, Martinez A, Pineda A (2004) Increased mast cell density and protease content in actinic cheilitis. J Oral Pathol Med 33:567-573

Rojas IG, Spencer ML, Martinez A (2005) Characterization of mast cell subpopulations in lip cancer. J Oral Pathol Med 34:268-273

Ruoss SJ, Hartmann T, Caughey GH (1991) Mast cell tryptase is a mitogen for cultured fibroblasts. J Clin Invest 88:493-499

Santos JN (2000) Expressão imuno-histoquímica de citoqueratinas, CD1a, S-100, p53, p21, PCNA E Ki-67 em queilite actínica. Thesis, University of São Paulo

Santos JN, Souza SO, Nunes FD et al (2003) Altered cytokeratin expression in actinic cheilitis. J Cutan Pathol 30:237-241

Schroder JM, Reich K, Kabashima K et al (2006) Who is really in control of skin immunity under physiological circumstanceslymphocytes, dendritic cells or keratinocytes? Exp Dermatol 15:913-929

Schwartz A, Grabbe S, Grosse-Heitemeyr K et al (1998) Ultraviolet light-induced immunetolerance is mediated via the Fas/Fasligand system. J Immunol 160:4262-4270
Takashima A (2005) UVB-dependent modulation of epidermal cytokine network roles in UVB-induced depletion of Langerhans cells and dendritic epidermal T cells. J Dermatol 22:876-887

Timares L, Katyar SK, Elmets CA (2008) DNA damage, apoptosis and Langerhans cells-activators of UV-induced immune tolerance. Photochem Photobiol 84:422-436

Valent P, Schernthaner GH, Sperr WR et al (2001) Variable expression of activation-linked surface antigens on human mast cells in health and disease. Immunol Rev 179:74-81

Wang HW, Tedla N, Hunt JE et al (2005) Mast cell accumulation and cytokine expression in the tight skin mouse model of scleroderma. Exp Dermatol 14:292-295

Welsh TJ, Green RH, Richardson D et al (2005) Macrophage and mast-cell invasion of tumor ell isçets confers a marked survival advantage in non-small-cell lung cancer. J Clin Oncol 23: 8959-8967 